The University of Maine

\title{
DigitalCommons@UMaine
}

Earth Science Faculty Scholarship

Earth Sciences

$1-1-1998$

\section{Thermochronological Evidence for Late Proterozoic (Vendian) Cooling in Southwest Wedel Jarlsberg Land, Spitsbergen}

\author{
M. Manecki \\ D. K. Holm \\ J. Czerny \\ Daniel R. Lux \\ University of Maine - Main, dlux@maine.edu
}

Follow this and additional works at: https://digitalcommons.library.umaine.edu/ers_facpub

Part of the Earth Sciences Commons

\section{Repository Citation}

Manecki, M.; Holm, D. K.; Czerny, J.; and Lux, Daniel R., "Thermochronological Evidence for Late Proterozoic (Vendian) Cooling in Southwest Wedel Jarlsberg Land, Spitsbergen" (1998). Earth Science Faculty Scholarship. 111.

https://digitalcommons.library.umaine.edu/ers_facpub/111 


\title{
Thermochronological evidence for late Proterozoic (Vendian) cooling in southwest Wedel Jarlsberg Land, Spitsbergen
}

\author{
M. MANECKI*II, D. K. HOLM*, J. CZERNY† \& D. LUX $\ddagger$ \\ * Department of Geology, Kent State University, Kent, Ohio 44242, USA \\ $\dagger$ Faculty of Geology, Geophysics and Env. Protection, Univ. of Mining and Metallurgy, 30-059 Krakow, Poland \\ † Department of Geological Sciences, University of Maine, Orono, Maine 04469, USA
}

(Received 18 March 1997; accepted 9 September 1997)

\begin{abstract}
Two Proterozoic terranes with different metamorphic histories are distinguished from geological mapping in southwestern Wedel Jarlsberg Land: a northern greenschist facies terrane and a southern amphibolite facies terrane which has been overprinted by greenschist facies metamorphism. To better characterize the tectonothermal history of these terranes we have obtained new ${ }^{40} \mathrm{Ar} /{ }^{39} \mathrm{Ar}$ mineral dates from this area. A muscovite separate from the northern terrane yielded a Caledonian plateau age of $432 \pm 7 \mathrm{Ma}$. The southern terrane yielded significantly older ${ }^{40} \mathrm{Ar} /{ }^{39} \mathrm{Ar}$ ages with three muscovite plateau dates of $584 \pm 14 \mathrm{Ma}$, $575 \pm 15 \mathrm{Ma}$, and $459 \pm 9 \mathrm{Ma}$, a $484 \pm 5 \mathrm{Ma}$ biotite plateau date, and a $616 \pm 17 \mathrm{Ma}$ hornblende plateau date. The oldest thermochronological dates are over 300 Ma younger than the age of amphibolite facies metamorphism and therefore probably do not represent uplift-related cooling. Instead, the Vendian dates correlate well with a regionally widespread magmatic and metamorphic/thermal resetting event recognized within Caledonian complexes of northwestern Spitsbergen and Nordaustlandet. The apparent Ordovician dates are interpreted to represent partial resetting, suggesting that late Caledonian greenschist facies overprinting of the southern terrane was of variable intensity.
\end{abstract}

\section{Introduction}

Most geological research conducted in the Arctic Svalbard archipelago (Fig. 1) during this century has concentrated on understanding the cycles of Phanerozoic tectonism during the Paleozoic (Caledonian) and Tertiary. In the past decade, however, field studies and new geochronological data are beginning to shed light on the island's preCaledonian history (e.g. Peucat et al. 1989; Bjørnerud, Craddock \& Wills, 1990; Dallmeyer, Peucat \& Ohta, 1990; Bernard-Griffiths, Peucat \& Ohta, 1993; Ohta, 1994; Balasov et al. 1995, 1996). In addition to documenting the Precambrian history of Svalbard, such studies are essential for differentiating polyphase Caledonian and Tertiary deformation from earlier structural features.

This study presents the first ${ }^{40} \mathrm{Ar} /{ }^{39} \mathrm{Ar}$ thermochronological data obtained from metamorphosed Proterozoic rocks in Wedel Jarlsberg Land, southwest Spitsbergen. Previous K/Ar studies from this area, as well as for most of west Spitsbergen, yield a range of dates from 595 to 337 Ma (Gayer et al. 1966; E. C. Hauser, unpub. Ph.D. thesis, Univ. Wisconsin, 1982; M. Bjørnerud, unpub. Ph.D. thesis, Univ. Wisconsin, 1987). More recently, Balasov et al. (1996) obtained a poorly constrained $\mathrm{Rb} / \mathrm{Sr}$ whole-rock errochron date of $c$. $600 \mathrm{Ma}$. A major question is whether these older dates reflect Caledonian overprinting of a Grenvillian tectonothermal event (Balasov et al.

II Author for correspondence: mmanecki@kent edu
1996) or alternatively, a separate metamorphic/thermal resetting event during Vendian time (Peucat et al. 1989).

We have concentrated on sampling metamorphosed late Precambrian bedrock from the southern portion of Wedel Jarlsberg Land. In contrast to the northern region which has only been metamorphosed to greenschist facies, this area exposes rocks affected by both an older amphibolite facies metamorphism and a younger greenschist facies metamorphism, making it more suited for attempts at dating late Proterozoic metamorphism/cooling. In addition, the two biotite K/Ar dates obtained from this area (565 and $595 \mathrm{Ma}$ : Gayer et al. 1966) represent some of the oldest thermochronological dates in Svalbard. Although only sparsely dated, the lack of Caledonian ages here suggests that ${ }^{40} \mathrm{Ar} /{ }^{39} \mathrm{Ar}$ dating may allow us to see through the Caledonian metamorphic overprint and back into the Proterozoic.

\section{Geological setting}

The metamorphic rocks exposed in western Spitsbergen are dominated by middle and late Proterozoic rocks of the Hecla Hoek Succession (Birkenmajer, 1992), all of which were deformed and metamorphosed during the Caledonian orogeny and variably overprinted by early Tertiary tectonothermal activity (Ohta, Dallmeyer \& Peucat, 1989). In the southern Wedel Jarlsberg Land (Fig. 2), new mapping by Czerny et al. (1993) indicates two Proterozoic terranes with different lithologies and metamorphic grades separated by a major Caledonian fault 

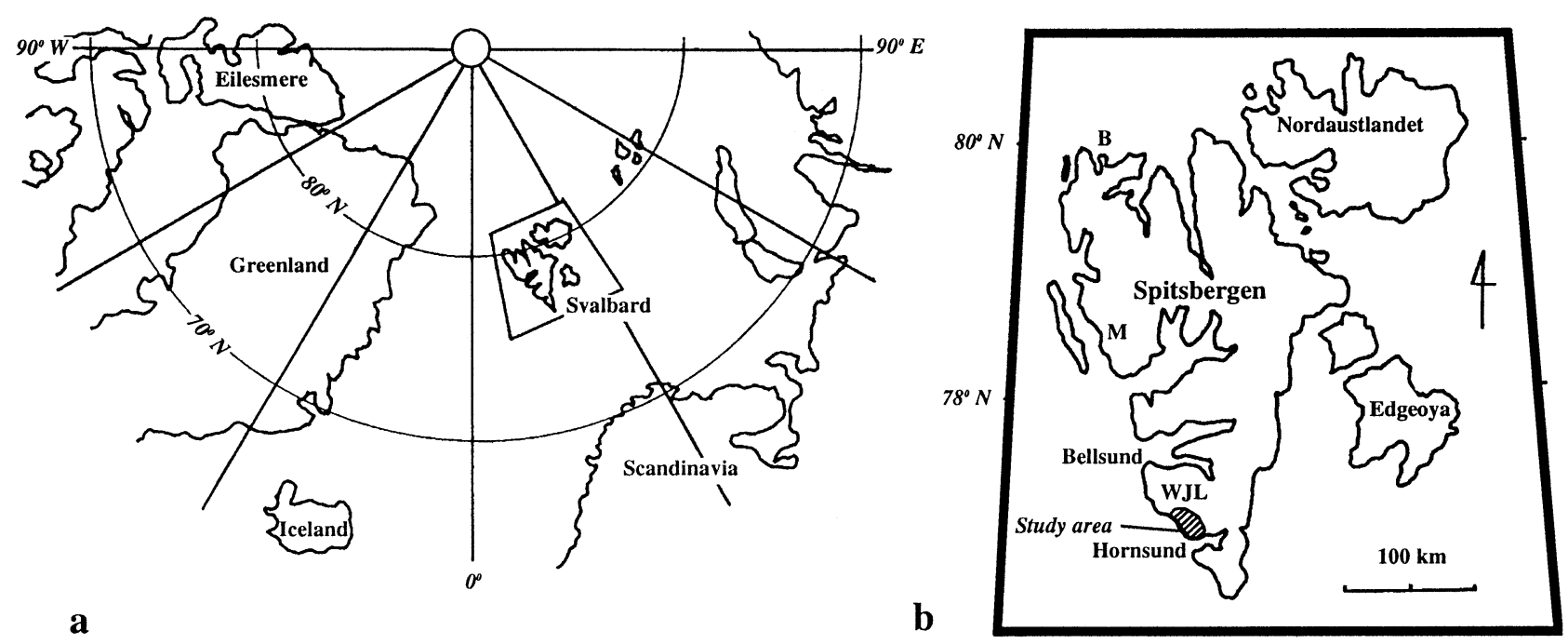

Figure 1. Location of Svalbard and Spitsbergen. (a) Scandinavian Arctic. (b) Location of the study area. M is the Motalafjella area and $\mathrm{B}$ is the Biskayer Peninsula.

zone (the Vimsodden-Kosibapasset fault). North of the Vimsodden-Kosibapasset fault an angular unconformity (the Torellian: Birkenmajer, 1975) separates more highly deformed strata of probable middle Proterozoic age (the Deilegga Group) from less deformed late Proterozoic rocks of the Sofiebogen Group (and Vendian diamictites). This unconformity almost certainly correlates with the late Proterozoic (pre-Vendian) angular unconformity recognized by Bjørnerud, Craddock \& Wills (1990) in the northern Wedel Jarlsberg Land. According to both Bjørnerud, Craddock \& Wills (1990) and Czerny et al. (1993), the structural contrasts across the unconformity suggest that the late Proterozoic deformational event involved large-scale translation of nappe-like structures. In spite of the contrasting deformational history, both rock sequences display only greenschist facies metamorphism.

South of the Vimsodden-Kosibapasset fault, paragneisses, mica schists and marbles of the Middle Proterozoic (?) Isbjørnhamna Group are overlain by the $\sim 1200-1100 \mathrm{Ma}$ igneous complex of the Eimfjellet Group (Balasov et al. 1995, 1996). The recent reinterpretation of the Vimsodden-Kosibapasset fault as a major Caledonian fault structure indicates that the stratigraphic relations north and south of the Vimsodden-Kosibapasset fault are unknown. In contrast to the northern terrane, the southern area has experienced two stages of metamorphism of differing degree: early epidote-amphibolite and amphibolite grade overprinted by retrogressive greenschist facies metamorphism. Recent U-Pb zircon and $\mathrm{Rb}-\mathrm{Sr}$ data suggest that the amphibolite metamorphism might be Grenvillian in age (Gavrilenko et al. 1993; Balasov et al. 1995). Based on the numerous Caledonian cooling ages north of this study area (Gayer et al. 1966; Horsfield, 1972; E. C. Hauser, unpub. Ph.D. thesis, Univ. Wisconsin, 1982), the greenschist facies metamorphism in both terranes has long been thought to be Caledonian in age. Among the youngest features in the region are two sets of Cretaceous dolerite dykes which are crosscut by north-northwest trending normal faults of Tertiary age (Fig. 2)

\section{Methodology}

After careful petrographic examination of a large suite of rock samples, one amphibolite, one silicic carbonate schist and four pelitic schists were selected for dating in this study. All samples selected are medium- to coarsegrained and exhibit well-developed metamorphic textures. The samples are essentially unaltered except for the existence of minor sericite in samples 2 and 4 and retrogressive chlorite around garnet rims in sample 4 and along minor fractures in sample 3 .

Sample preparation, irradiation and analytical procedures for ${ }^{40} \mathrm{Ar} /{ }^{39} \mathrm{Ar}$ incremental release dating follow the procedures described by Lux (1986). Ultra-pure (99\%) samples were encapsulated in tin foil and irradiated in the L67 facility of the Ford Reactor at the Phoenix Memorial Laboratory reactor of the University of Michigan. Variations in neutron flux during irradiation were monitored with the University of Maine flux monitor SBG-7 $($ age $=240.9 \mathrm{Ma}$ relative to MMhb-1 $(519.5 \mathrm{Ma})$ : Alexander, Michelson \& Lanphere, 1978). The samples were heated in a molybdenum crucible using radio frequency induction within an ultra-high vacuum system, on a line to a Nuclide model 6-60-SGA mass spectrometer. Samples were analysed by the incremental heating technique in which the sample is heated repeatedly at successively higher temperatures. Sample localities are plotted on Figure 2, analytical data and stratigraphic position are listed in Table 1, and results are presented in Figure 3 as release spectra in which the horizontal width of each box represents the size of an increment relative to the others and the height represents the uncertainty associated with each apparent age. Uncertainties were calculated by the method described in Dalrymple et al. (1981), are reported at the $2 \sigma$ level, and include the uncertainty in the flux 


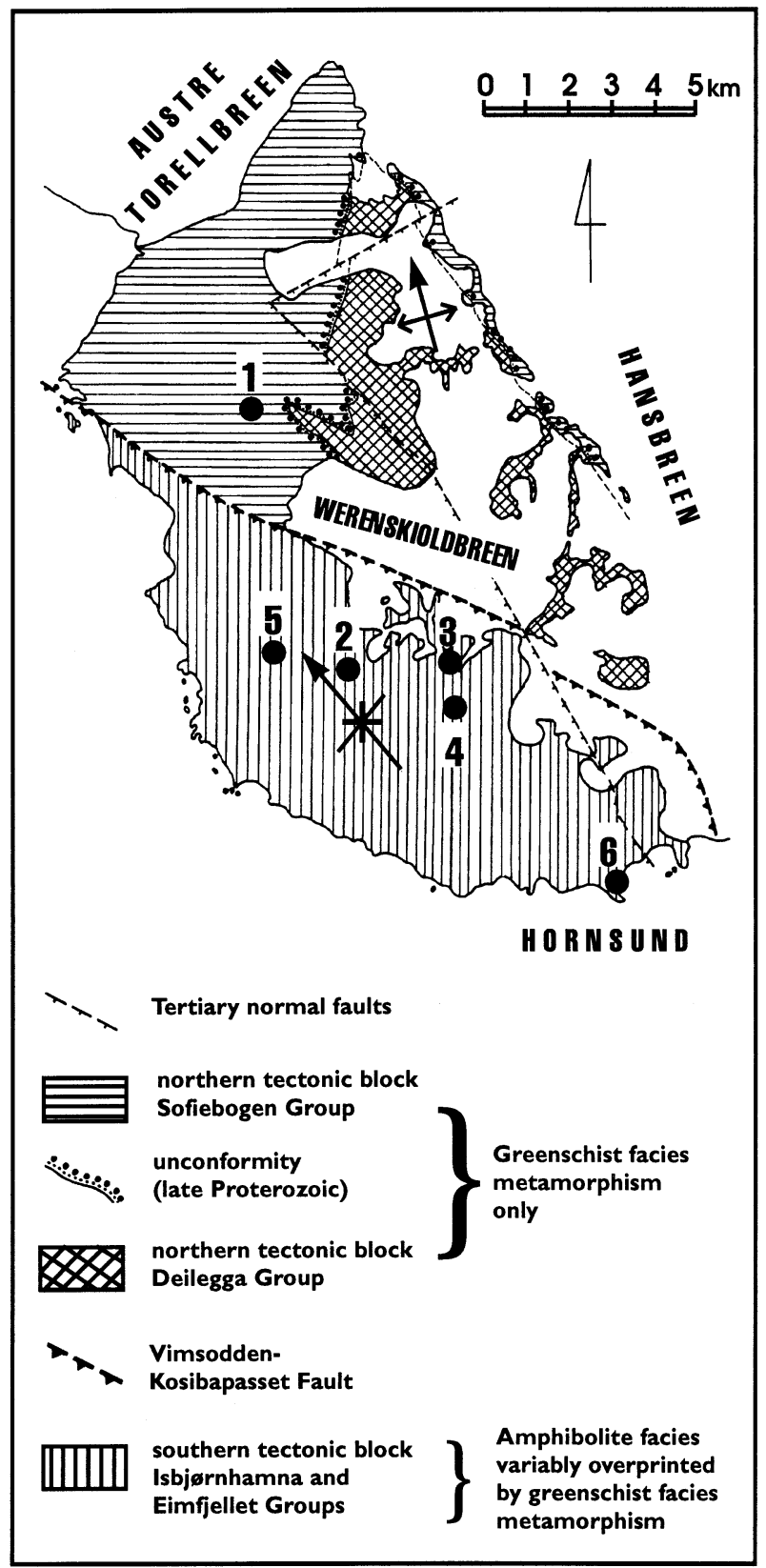

Figure 2. Simplified schematic map of the southwest part of Wedel Jarlsberg Land with sample locations (after Czerny et al. 1993).

measurement (J value). Standard closure temperatures of $300 \pm 50{ }^{\circ} \mathrm{C}$ for biotite, $350 \pm 50^{\circ} \mathrm{C}$ for muscovite, and $500 \pm 50{ }^{\circ} \mathrm{C}$ for hornblende are assumed (McDougall \& Harrison, 1988).

\section{Results}

Hornblende separated from an amphibolite schist from the southern terrane (sample 2, Fig. 2) exhibited a partially disturbed spectrum (Fig. 3). The low temperature increments yielded relatively young dates ( 370-430 Ma) which then increased monotonically and leveled off over the last four increments ( $70 \%$ of the total gas released) to give a plateau age of $616 \pm 17 \mathrm{Ma}$. Muscovite separates

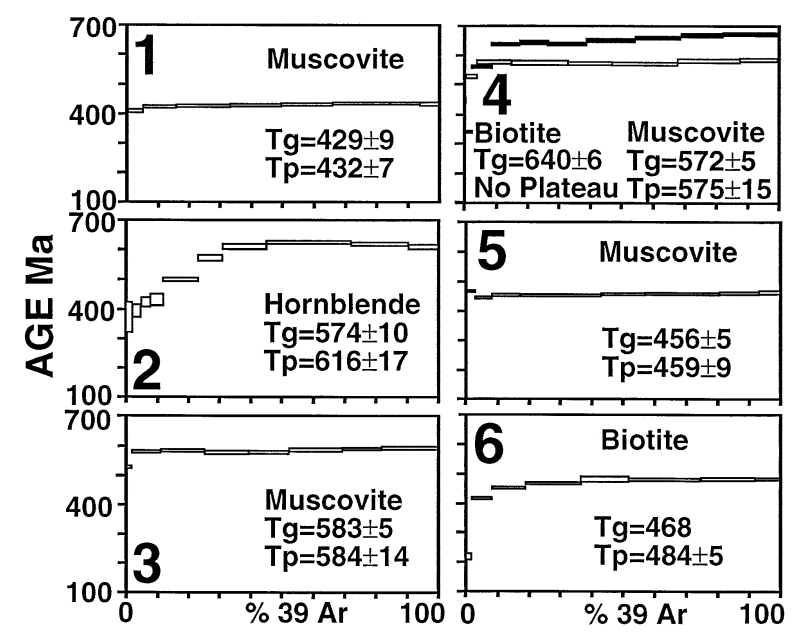

Figure 3. Ar/Ar release spectra diagrams. Tg - total gas age; Tp - plateau age.

from two garnet-mica schists, also from the southern terrane (samples 3 and 4), yielded somewhat younger concordant plateau dates of $584 \pm 14 \mathrm{Ma}$ and $575 \pm 15 \mathrm{Ma}$. In both samples the plateau dates are defined by over $95 \%$ of the gas with only a very small proportion of the gas in the first one or two increments yielding younger dates of $450 \mathrm{Ma}$ to $525 \mathrm{Ma}$. A third muscovite separate (sample 5) from a muscovite schist of the southern terrane yielded a significantly younger concordant total gas and plateau date of $459 \pm 9 \mathrm{Ma}$. Muscovite from a muscovite-carbonate-quartz schist from the northern greenschist facies terrane (sample 1) yielded a concordant total gas and plateau date (constituting $95 \%$ of the total gas released) of $432 \pm 7$ Ma (Fig. 3).

Two biotite separates were dated from the southern metamorphic terrane. Biotite from the garnet-mica schist sample 4 yielded a total gas age significantly older than the $575 \mathrm{Ma}$ muscovite plateau date obtained from the same rock. All increments record systematically increasing apparent dates up to a maximum of $\sim 671 \mathrm{Ma}$. The lack of a plateau and the fact that most of the increments yield dates older than that obtained for coexisting muscovite suggests to us that this biotite separate has been contaminated with unresolved excess ${ }^{40} \mathrm{Ar}$. Preferential intake of excess ${ }^{40} \mathrm{Ar}$ into biotite over coexisting muscovite is well known (Brewer, 1969). Biotite from sample 6 yielded a slightly disturbed spectrum with an initial low-temperature age increment of $210 \mathrm{Ma}$. Subsequent age increments increased quickly until the sample yielded a $484 \pm 5$ Ma plateau age (constituting $\sim 60 \%$ of the total gas released).

\section{Geological significance}

As noted above, the only previously published thermochronological data from this region are $565 \mathrm{Ma}$ and $595 \mathrm{Ma}$ biotite K/Ar dates from the Isbjørnhamna Group rocks of the southern tectonic block (Gayer et al. 1966). Given the amphibolite grade of metamorphism, these 
Table 1. Ar/Ar analytical data for incremental heating experiments on mineral concentrates from southwest Wedel Jarlsberg Land, Spitsbergen

\begin{tabular}{|c|c|c|c|c|c|c|c|c|}
\hline $\begin{array}{l}\text { Temp. } \\
\left({ }^{\circ} \mathrm{C}\right)\end{array}$ & ${ }^{40} \mathrm{Ar} /{ }^{\beta 9} \mathrm{Ar}$ & ${ }^{37} \mathrm{Ar} /{ }^{39} \mathrm{Ar}$ & ${ }^{36} \mathrm{Ar} /{ }^{39} \mathrm{Ar}$ & $\begin{array}{c}{ }^{39} \mathrm{Ar} \\
\text { (moles*) }\end{array}$ & $\begin{array}{c}{ }^{39} \mathrm{Ar} \\
(\% \text { of total) }\end{array}$ & $\begin{array}{c}{ }^{40} \mathrm{Ar}_{\mathrm{rad}} \\
(\%)\end{array}$ & $\mathrm{K} / \mathrm{Ca}$ & $\begin{array}{l}\text { Age } \\
(\mathrm{Ma})\end{array}$ \\
\hline \multicolumn{9}{|c|}{ (1) SP72/85-Muscovite: Muscovite-carbonate-quartz schist, Slyngfjellet Formation, Sofiebogen Group $(\mathrm{J}=0.007963)$} \\
\hline 770 & 33.39 & 0.119 & 0.0051 & 291.9 & 5.5 & 95.4 & 4.1 & $407.9 \pm 6.7$ \\
\hline 915 & 33.65 & 0.035 & 0.0011 & 566.3 & 10.7 & 99.0 & 13.9 & $424.5 \pm 4.3$ \\
\hline 1020 & 34.01 & 0.002 & 0.0016 & 917.4 & 17.3 & 98.5 & 231.5 & $426.7 \pm 4.0$ \\
\hline 1080 & 34.09 & 0.012 & 0.0011 & 870.5 & 16.4 & 98.9 & 39.6 & $429.2 \pm 4.0$ \\
\hline 1145 & 34.19 & 0.016 & 0.0008 & 871.1 & 16.4 & 99.2 & 31.5 & $431.4 \pm 4.0$ \\
\hline 1235 & 34.33 & 0.015 & 0.0007 & 974.4 & 18.4 & 99.3 & 33.4 & $433.4 \pm 4.0$ \\
\hline 1310 & 34.64 & 0.032 & 0.0011 & 501.5 & 9.5 & 99.0 & 15.3 & $435.6 \pm 4.2$ \\
\hline Fuse & 35.31 & 0.094 & 0.0043 & 304.4 & 5.7 & 96.4 & 5.2 & $432.7 \pm 6.9$ \\
\hline Total & & & & 5297.5 & 100.0 & & & $429.0 \pm 8.8$ \\
\hline Plateau age & & & & & & & & $432.5 \pm 6.9$ \\
\hline \multicolumn{9}{|c|}{ (2) SP2G/89-Hornblende: Amphibolite, Eimfjellbreane Formation, Eimfjellet Group (J = 0.007625) } \\
\hline 770 & 79.42 & 2.174 & 0.1996 & 16.3 & 0.8 & 25.9 & 0.2 & $263.4 \pm 133.1$ \\
\hline 860 & 50.46 & 1.171 & 0.0688 & 36.3 & 1.8 & 59.8 & 0.4 & $374.0 \pm 48.7$ \\
\hline 945 & 41.83 & 1.252 & 0.0339 & 55.1 & 2.7 & 76.2 & 0.4 & $393.0 \pm 21.4$ \\
\hline 1020 & 39.57 & 2.149 & 0.0173 & 58.7 & 2.9 & 87.4 & 0.2 & $422.9 \pm 16.5$ \\
\hline 1080 & 39.37 & 4.454 & 0.0153 & 82.2 & 4.0 & 89.3 & 0.1 & $429.6 \pm 20.3$ \\
\hline 1145 & 43.99 & 8.310 & 0.0107 & 229.4 & 11.3 & 94.2 & 0.1 & $497.9 \pm 7.0$ \\
\hline 1200 & 49.14 & 11.030 & 0.0046 & 165.2 & 8.1 & 98.9 & 0.0 & $572.2 \pm 11.8$ \\
\hline 1260 & 55.55 & 12.252 & 0.0140 & 283.6 & 13.9 & 94.2 & 0.0 & $609.8 \pm 9.1$ \\
\hline 1310 & 61.16 & 13.034 & 0.0283 & 549.0 & 27.0 & 87.9 & 0.0 & $624.3 \pm 6.1$ \\
\hline 1360 & 60.97 & 12.801 & 0.0295 & 372.1 & 18.3 & 87.3 & 0.0 & $618.9 \pm 6.6$ \\
\hline Fuse & 60.80 & 12.472 & 0.0320 & 186.1 & 9.1 & 86.0 & 0.0 & $609.6 \pm 7.8$ \\
\hline Total & & & & 2034.0 & 100.0 & & & $574.2 \pm 10.4$ \\
\hline Plateau age & & & & & & & & $615.7 \pm 17.5$ \\
\hline \multicolumn{9}{|c|}{ (3) SP17M/88-Muscovite: Garnet-mica schist, Revdalen Formation, Isbjørnhamna Group (J = 0.00762) } \\
\hline 770 & 47.96 & 0.035 & 0.0117 & 186.5 & 2.2 & 92.7 & 13.9 & $526.6 \pm 5.6$ \\
\hline 915 & 50.62 & 0.004 & 0.0026 & 815.5 & 9.4 & 98.4 & 110.3 & $580.5 \pm 5.1$ \\
\hline 1020 & 50.72 & 0.005 & 0.0021 & 1232.1 & 14.3 & 98.7 & 92.6 & $583.2 \pm 5.1$ \\
\hline 1080 & 50.17 & 0.005 & 0.0019 & 1204.0 & 13.9 & 98.8 & 106.8 & $578.3 \pm 5.0$ \\
\hline 1145 & 50.01 & 0.007 & 0.0018 & 1110.3 & 12.8 & 98.9 & 72.4 & $577.1 \pm 5.0$ \\
\hline 1235 & 50.57 & 0.006 & 0.0010 & 1475.0 & 17.1 & 99.4 & 80.6 & $584.8 \pm 5.0$ \\
\hline 1310 & 51.10 & 0.006 & 0.0012 & 1091.3 & 12.6 & 99.2 & 76.6 & $589.5 \pm 5.1$ \\
\hline Fuse & 51.37 & 0.014 & 0.0014 & 1526.2 & 17.7 & 99.1 & 35.1 & $591.6 \pm 5.1$ \\
\hline Total & & & & 8641.0 & 100.0 & & & $582.8 \pm 5.1$ \\
\hline Plateau age & & & & & & & & $583.6 \pm 13.9$ \\
\hline \multicolumn{9}{|c|}{ (4) SP6M/88-Muscovite: Garnet-mica schist, Skoddefjellet Formation, Isbjørnhamna Group (J = 0.007523) } \\
\hline 770 & 42.46 & 0.073 & 0.0162 & 80.8 & 0.9 & 88.7 & 6.7 & $450.0 \pm 10.6$ \\
\hline 915 & 46.66 & 0.022 & 0.0058 & 309.4 & 3.6 & 96.3 & 22.7 & $525.2 \pm 6.4$ \\
\hline 1020 & 50.64 & 0.012 & 0.0028 & 933.8 & 11.0 & 98.3 & 39.9 & $574.0 \pm 5.3$ \\
\hline 1080 & 50.42 & 0.008 & 0.0017 & 1526.2 & 17.9 & 99.0 & 58.5 & $575.1 \pm 5.1$ \\
\hline 1145 & 49.56 & 0.006 & 0.0013 & 1202.5 & 14.1 & 99.2 & 80.9 & $567.7 \pm 5.0$ \\
\hline 1235 & 49.79 & 0.010 & 0.0014 & 1782.8 & 20.9 & 99.1 & 49.5 & $569.7 \pm 5.0$ \\
\hline 1310 & 50.56 & 0.007 & 0.0007 & 1686.7 & 19.8 & 99.5 & 66.9 & $579.2 \pm 5.0$ \\
\hline Fuse & 51.08 & 0.007 & 0.0009 & 993.3 & 11.7 & 99.4 & 73.6 & $583.7 \pm 5.2$ \\
\hline Total & & & & 8515.4 & 100.0 & & & $571.6 \pm 5.2$ \\
\hline Plateau age & & & & & & & & $574.9 \pm 14.7$ \\
\hline \multicolumn{9}{|c|}{ (4) SP6M/88-Biotite: (J = 0.007925) } \\
\hline 660 & 31.21 & 0.028 & 0.0171 & 375.8 & 2.8 & 83.8 & 17.7 & $339.7 \pm 4.3$ \\
\hline 770 & 49.12 & 0.023 & 0.0108 & 834.5 & 6.2 & 93.5 & 21.0 & $560.0 \pm 5.0$ \\
\hline 860 & 54.59 & 0.006 & 0.0039 & 1226.1 & 9.1 & 97.9 & 76.2 & $637.0 \pm 6.3$ \\
\hline 945 & 55.21 & 0.012 & 0.0046 & 1216.3 & 9.0 & 97.5 & 40.1 & $641.1 \pm 5.8$ \\
\hline 1035 & 54.90 & 0.013 & 0.0048 & 1665.3 & 12.3 & 97.4 & 39.0 & $637.4 \pm 5.7$ \\
\hline 1105 & 55.88 & 0.010 & 0.0037 & 2085.0 & 15.4 & 98.0 & 48.6 & $650.3 \pm 6.2$ \\
\hline 1180 & 56.58 & 0.012 & 0.0032 & 1954.4 & 14.4 & 98.3 & 41.4 & $658.9 \pm 5.9$ \\
\hline 1250 & 57.28 & 0.029 & 0.0026 & 1810.5 & 13.4 & 98.6 & 16.8 & $667.4 \pm 6.9$ \\
\hline 1310 & 57.49 & 0.019 & 0.0023 & 1466.4 & 10.8 & 98.8 & 25.6 & $670.5 \pm 5.8$ \\
\hline Fuse & 58.06 & 0.030 & 0.0042 & 896.7 & 6.6 & 97.9 & 16.3 & $670.7 \pm 6.6$ \\
\hline Total & & & & 13531.0 & 100.0 & & & $639.6 \pm 6.0$ \\
\hline No plateau & & & & & & & & \\
\hline
\end{tabular}

dates cannot be considered 'mixed' ages of remnant detrital minerals (within the protolith) and recrystallized metamorphic minerals. Our new $616 \mathrm{Ma}$ hornblende plateau date and the $584 \mathrm{Ma}$ and $575 \mathrm{Ma}$ muscovite plateau dates from the southern terrane are roughly concordant with the K/Ar biotite dates suggesting a period of latest Proterozoic cooling of the amphibolite terrane from temperatures above $500{ }^{\circ} \mathrm{C}$ to below $300{ }^{\circ} \mathrm{C}$ (Fig. 4). The age of initial 
Table 1-cont.

\begin{tabular}{|c|c|c|c|c|c|c|c|c|}
\hline $\begin{array}{l}\text { Temp. } \\
\left({ }^{\circ} \mathrm{C}\right)\end{array}$ & ${ }^{40} \mathrm{Ar} /{ }^{39} \mathrm{Ar}$ & ${ }^{37} \mathrm{Ar} /{ }^{39} \mathrm{Ar}$ & ${ }^{36} \mathrm{Ar} /{ }^{39} \mathrm{Ar}$ & $\begin{array}{c}{ }^{39} \mathrm{Ar} \\
(\text { moles*) }\end{array}$ & $\begin{array}{c}{ }^{39} \mathrm{Ar} \\
(\% \text { of total) }\end{array}$ & $\begin{array}{c}{ }^{40} \mathrm{Ar}_{\mathrm{rad}} \\
(\%)\end{array}$ & $\mathrm{K} / \mathrm{Ca}$ & $\begin{array}{l}\text { Age } \\
(\mathrm{Ma})\end{array}$ \\
\hline \multicolumn{9}{|c|}{ (5) SP17D/89-Muscovite: Muscovite schist, Bratteggdalen Formation, Eimfjellet Group $(\mathrm{J}=0.007503)$} \\
\hline 770 & 40.30 & 0.012 & 0.0031 & 345.3 & 3.3 & 97.7 & 40.8 & $467.0 \pm 4.9$ \\
\hline 915 & 37.72 & 0.017 & 0.0011 & 547.8 & 5.2 & 99.1 & 28.9 & $445.9 \pm 4.3$ \\
\hline 1020 & 38.03 & 0.001 & 0.0001 & 927.2 & 8.9 & 99.9 & 401.5 & $452.5 \pm 4.1$ \\
\hline 1080 & 38.13 & 0.004 & 0.0004 & 2744.4 & 26.2 & 99.7 & 109.5 & $452.6 \pm 4.2$ \\
\hline 1140 & 38.40 & 0.000 & 0.0001 & 1460.3 & 13.9 & 99.9 & 4029.6 & $456.3 \pm 5.4$ \\
\hline 1235 & 38.61 & 0.004 & 0.0005 & 2465.0 & 23.5 & 99.5 & 117.6 & $457.1 \pm 4.3$ \\
\hline 1310 & 38.89 & 0.005 & 0.0003 & 1299.3 & 12.4 & 99.7 & 93.8 & $460.6 \pm 4.8$ \\
\hline Fuse & 39.24 & 0.006 & 0.0008 & 683.8 & 6.5 & 99.4 & 78.0 & $463.0 \pm 5.0$ \\
\hline Total & & & & 10473.1 & 100.0 & & & $456.0 \pm 4.5$ \\
\hline Plateau & & & & & & & & $458.7 \pm 8.8$ \\
\hline \multicolumn{9}{|c|}{ (6) SP49M/88-Biotite: Garnet-mica schist, Revdalen Formation, Isbjørnhamna Group (J = 0.007738) } \\
\hline 770 & 22.135 & 0.024 & 0.0183 & 184.8 & 2.3 & 75.5 & 20.6 & $219.5 \pm 10.7$ \\
\hline 915 & 35.600 & 0.016 & 0.0062 & 522.2 & 6.4 & 94.8 & 30.9 & $418.5 \pm 4.1$ \\
\hline 1020 & 37.981 & 0.005 & 0.0032 & 865.0 & 10.6 & 97.5 & 89.4 & $454.4 \pm 4.2$ \\
\hline 1080 & 39.034 & 0.010 & 0.0022 & 1467.7 & 17.9 & 98.3 & 51.2 & $469.0 \pm 4.2$ \\
\hline 1145 & 40.153 & 0.009 & 0.0013 & 1237.1 & 15.1 & 99.0 & 55.2 & $483.9 \pm 7.2$ \\
\hline 1235 & 39.892 & 0.015 & 0.0009 & 1871.5 & 22.9 & 99.3 & 32.6 & $482.4 \pm 4.3$ \\
\hline 1310 & 40.036 & 0.020 & 0.0008 & 1396.3 & 17.1 & 99.3 & 24.2 & $484.1 \pm 4.4$ \\
\hline Fuse & 40.170 & 0.037 & 0.0010 & 644.2 & 7.9 & 99.2 & 13.1 & $485.1 \pm 4.9$ \\
\hline Total & & & & 8188.6 & 100.0 & & & $467.8 \pm 4.9$ \\
\hline Plateau & & & & & & & & $483.9 \pm 4.7$ \\
\hline
\end{tabular}

$* \times 10^{-14}$

low-temperature increments of the hornblende sample suggests it has been partially reset during the Caledonian. However, the fact that the hornblende plateau date is not significantly older than the mica dates (both Ar/Ar muscovite and $\mathrm{K} / \mathrm{Ar}$ biotite) suggests that the plateau age is probably not a partially reset date (e.g. from a Grenvillian metamorphism).

These Vendian dates from the amphibolite terrane contrast with significantly older Grenvillian U-Pb zircon dates recently reported by Balasov et al. (1995) from a rhyolitic metaconglomerate (Eimfjellet Group). Magmatic clasts in the metaconglomerate yield concordia or near concordia zircon dates of c. $1200 \mathrm{Ma}$. However, some of the zircons are discordant and give lower intercept ages in the range of 919-933 Ma. This age range is concordant with a preliminary $\mathrm{Rb}-\mathrm{Sr}$ whole rock age of $936 \pm 15 \mathrm{Ma}$ obtained from garnet-biotite schists of the Isbjørnhamna Group by Gavrilenko et al. (1993). Accordingly, Balasov et al. (1995) interpreted the amphibolite facies metamorphism of the southern terrane to be Grenvillian in age. Their interpretation is consistent with field evidence for a major late Proterozoic (preVendian) deformational event in the Wedel Jarlsberg Land (Bjørnerud, Craddock \& Wills, 1990; Czerny et al. 1993).

Barring partial resetting from Grenvillian time (see Balasov et al. 1996), our oldest dates suggest a period of moderately rapid cooling of the amphibolite terrane approximately $300 \mathrm{Ma}$ after Grenvillian metamorphism. Given the long time span between metamorphism and cooling, it seems unlikely that the Vendian dates would reflect the time of initial uplift and cooling of the middle crust (Fig. 4), especially considering that amphibolite

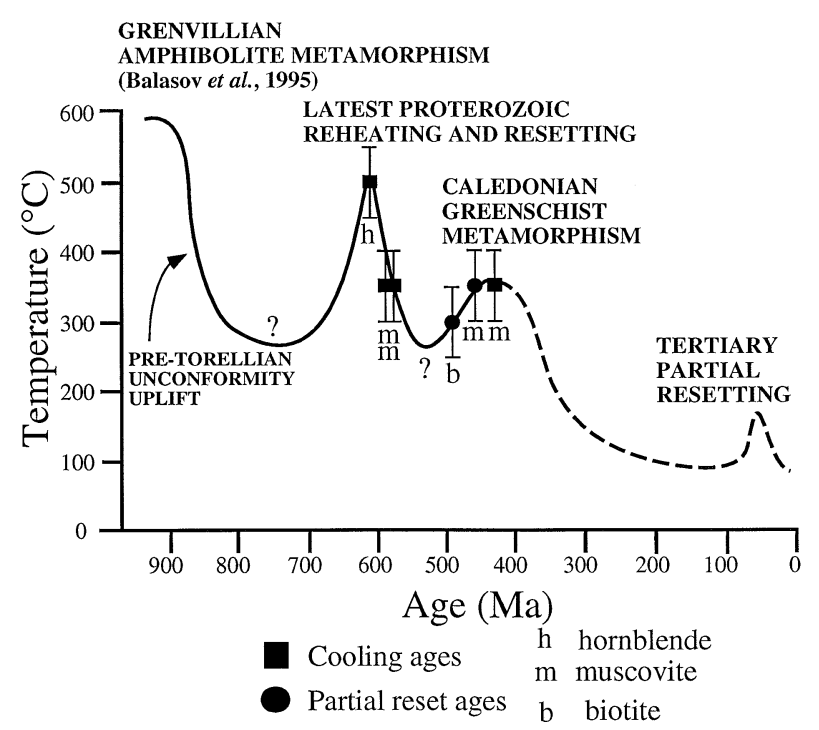

Figure 4. Proposed composite time-temperature reconstruction for metamorphic rocks of the southwestern part of Wedel Jarlsberg Land.

facies metamorphism is in places low-grade (that is, epidote-amphibolite: Czerny et al. 1993). In addition, if we assume that the southern terrane merely represents a deeper exposed portion of the northern terrane, then the presence of the late Proterozoic Torellian unconformity in the northern terrane suggests significant erosion and uplift after Grenvillian metamorphism and deformation and before deposition of the latest Proterozoic Sofiebogen Group. Finally, Czerny et al. (1993) present evidence of dropstones in some of the youngest sediments of the Sofiebogen Group and correlate them stratigraphically to 
the widespread Vendian (Kapp Lyell) Diamictites. This indicates that the study area was part of a regionally widespread area of deposition during Vendian times and therefore was probably not experiencing moderately rapid uplift.

We note that the Vendian cooling dates obtained here correlate well with a latest Proterozoic eclogitic metamorphism recognized by $\mathrm{U}-\mathrm{Pb}$ zircon dating on the Biskayer Peninsula of northwestern Spitsbergen (Fig. 1; Peucat et al. 1989). Similar isotopic mineral dates of $\sim 600$ Ma from both igneous and metamorphic rocks have also been reported from Nordaustlandet (Hamilton \& Sandford, 1964; Lauritzen \& Ohta, 1984). We interpret our hornblende plateau date and oldest muscovite dates as cooling following a transient thermal event (Fig. 4). The Vendian dates from southern Spitsbergen lend credence to the possibility that Vendian magmatism and thermal resetting (Fig. 4) may have been widespread in the various Svalbard lithotectonic units (Ohta, Dallmeyer \& Peucat, 1989), although there is no direct evidence for Vendian plutonism in southern Spitsbergen.

The greenschist facies metamorphism of the youngest Proterozoic rocks in the northern terrane (the Sofiebogen Group) has long been thought to be Caledonian in age and the muscovite plateau date of $432 \pm 7 \mathrm{Ma}$ from that terrane clearly confirms this. However, this does not necessarily mean that all greenschist facies metamorphism in the northern terrane is only Caledonian in age. The angular unconformity underlying the Sofiebogen Group (Birkenmajer, 1975) separates it from more highly deformed Proterozoic strata of the Deilegga sequence and the unconformity almost certainly correlates with the late Proterozoic (pre-Vendian) angular unconformity recognized by Bjørnerud, Craddock \& Wills (1990) in the northern Wedel Jarlsberg Land. Surprisingly, as noted by Bjørnerud, Craddock \& Wills (1990), there is no obvious metamorphic contrast between sequences above and below the unconformity although A. Cheng (unpub. Ph.D. thesis, Univ. Wisconsin, 1984) did report the local existence of kyanite in a quartzite below the unconformity in the northern Wedel Jarlsberg Land (north of Torellbreen). Therefore, it is possible that at least some of the greenschist metamorphism of the underlying Deilegga sequence could be late Proterozoic in age and may well actually correlate with the $c .930 \mathrm{Ma}$ age of metamorphism of the southern terrane (Balasov et al. 1995). The lack of any thermochronological data from the Deilegga sequence precludes us at present from directly determining the age of greenschist metamorphism beneath the angular unconformity.

Detailed thermochronological studies from other regions of western Spitsbergen have documented polyphase Caledonian tectonothermal events with early Caledonian metamorphism occurring at 500-540 Ma on the Biskayer Peninsula (Dallmeyer, Peucat \& Ohta, 1990) and at 460-470 Ma in the Motalafjella area (Dallmeyer et al. 1990) and late Caledonian metamorphism occurring synchronously in both regions at 380-440 Ma. We do not, however, interpret the apparent Ordovician plateau dates obtained from the southern terrane (459 Ma muscovite and $484 \mathrm{Ma}$ biotite) as resulting from a separate early Caledonian metamorphism as documented in those regions. For one thing, the Ordovician metamorphism in the Motalafjella area is a high-pressure metamorphism (blueschist-eclogite) and therefore distinctly different from the post-Vendian low-grade (greenschist) overprinting metamorphism of the southern terrane studied here. Secondly, it seems unlikely that the late Caledonian (430 Ma) greenschist metamorphism of the northern terrane would be younger than the greenschist overprinting metamorphism of the southern terrane. Previous studies (summarized in Ohta, Dallmeyer \& Peucat, 1989) have shown that the entire western area of Spitsbergen was thermally affected by the late Caledonian metamorphism (at $\sim 380-440 \mathrm{Ma}$ ) and it therefore seems unlikely that the southern terrane could have avoided it. Indeed, the age of the low temperature increments from the hornblende sample strongly suggests at least mild thermal overprinting of the southern terrane at about 350-430 Ma. We interpret the Ordovician mica dates (samples 5 and 6) as resulting from partial resetting of older Vendian cooling dates during late Caledonian greenschist metamorphism (Fig. 4). This interpretation implies that late Caledonian metamorphism was of variable intensity in western Spitsbergen. Dallmeyer, Peucat \& Ohta (1990) came to a similar conclusion from their thermochronological study of the Biskayer Peninsula.

Finally, one of the biotite spectra (sample 6) displays a low-temperature increment suggestive of a slight postCaledonian (<210 Ma) thermal disturbance. Dallmeyer (1989) obtained a similar-aged, although somewhat more pronounced, discordance from muscovite of west-central Spitsbergen. These data, as well as evidence for postMesozoic thermal overprinting in the Motalafjella region (Dallmeyer et al. 1990) attest to a weak but apparently widespread thermal influence associated with the Tertiary orogeny (Fig. 4).

\section{Conclusions}

Detailed field mapping of the southern Wedel Jarlsberg Land by Czerny et al. (1993) and the new thermochronological data presented here lead us to suggest the following late Proterozoic to Caledonian tectonothermal history (Fig. 4):

(1) Proterozoic rocks of the southern terrane and perhaps the shallower-level sub-Torellian unconformity Proterozoic (Deilegga Group) rocks of the northern terrane were deformed and variably metamorphosed (possible greenschist in the north and amphibolite in the south) at $\sim 930 \mathrm{Ma}$ (Balasov et al. 1995).

(2) Late Proterozoic erosional unroofing was followed by deposition of Sofiebogen Group sediments on lowgrade, but highly deformed Deilegga Group rocks.

(3) Complete thermal resetting of the deeperseated southern terrane occurred during the Vendian and 
is interpreted to represent a probably magmatic-related event which was apparently widespread across Svalbard.

(4) North-directed thrusting along the VimsoddenKosibapasset fault juxtaposed the two metamorphic terranes during the Caledonian orogeny (Czerny et al. 1993).

(5) Caledonian-age thrusting and folding of both terranes was concomitant with greenschist-facies metamorphism of the Sofiebogen Group (and underlying Deilegga Group) and variable greenschist-facies overprinting of the southern tectonic block.

Acknowledgements. Samples were collected during Geological Polar Expeditions organized by the Univ. of Mining and Metallurgy in Krakow under the leadership of A. Manecki. We thank P. Dahl for thoughtful input and discussion and Dan Griffiths for laboratory assistance. The original manuscript was improved by the review of Y. Ohta. This work was supported, in part, from a Kent State University Faculty Incentive Award and by the Academy of Mining and Metallurgy research fund (contract 11.140.408).

\section{References}

Alexander, E. C. JR., Michelson, G. M. \& Lanphere, M. A. 1978. MMhb-1: A new ${ }^{40} \mathrm{Ar} /{ }^{39} \mathrm{Ar}$ dating standard. In Fourth International Conference on Geochronology, Cosmochronology, and Isotope Geology (ed. R. E. Zartman), pp. 6-8. U.S. Geological Survey Open-File Rept. no. 78-701.

Balasov, Ju. A., Tebenkov, A. M., Ohta, Y., Larionov, A. N., Sirotkin, A. N., Gannibal, L. F. \& Ryungenen, G. I. 1995. Grenvillian U-Pb zircon ages of quartz porphyry and rhyolite clasts in a metaconglomerate at Vimsodden, southwestern Spitsbergen. Polar Research 14, 291-302.

Balasov, Ju. A., Peucat, J. J., Tebenkov, A. M., Ohta, Y., Larionov, A. N., Sirotkin, A. N. \& BJØRNERUd, M. 1996. $\mathrm{Rb}-\mathrm{Sr}$ whole rock and $\mathrm{U}-\mathrm{Pb}$ zircon datings of the granitic-gabbroic rocks from the Skalfjellet Subgroup, southwest Spitsbergen. Polar Research 15, 167-81.

Bernhard-Griffiths, J., Peucat, J. J. \& Ohta, Y. 1993. Age and nature of some protoliths in the Caledonian blueschisteclogite complex of western Spitsbergen: A combined approach using $\mathrm{U}-\mathrm{Pb}, \mathrm{Sm}-\mathrm{Nd}$, and REE geochemistries. Lithos 30, 81-90.

BirkenMAJER, K. 1975. Caledonides of Svalbard and plate tectonics. Bulletin Geological Society of Denmark 24, 1-19.

BIRKENMAJER, K. 1992. Precambrian succession at Hornsund, south Spitsbergen: A lithostratigraphic guide. Studia Geologica Polonica 98, 67-105.

Bjørnerud, M., Craddock, C. \& Wills, C. J. 1990. A major late Proterozoic tectonic event in southwestern Spitsbergen. Precambrian Research 48, 157-65.

BREWER, M. S. 1969. Excess radiogenic argon in metamorphic micas from the eastern Alps, Austria. Earth and Planetary Science Letters 6, 321-31.
Czerny, J., Kieres, A., Manecki, M. \& Rajchel, J. 1993. Geological map of the SW part of Wedel Jarlsberg Land, Spitsbergen, 1:25000. (ed. A. Manecki), pp. 1-61. Institute of Geology and Mineral Deposits, Cracow.

DALLMEYER, R. D. 1989. Partial thermal resetting of ${ }^{40} \mathrm{Ar} /{ }^{39} \mathrm{Ar}$ mineral ages in western Spitsbergen, Svalbard: Possible evidence for Tertiary metamorphism. Geological Magazine 126, 587-93.

Dallmeyer, R. D., Peucat, J. J. \& Ohta, Y. 1990. Tectonothermal evolution of contrasting metamorphic complexes in northwest Spitsbergen (Biskayerhalvøya): evidence from ${ }^{40} \mathrm{Ar} /{ }^{39} \mathrm{Ar}$ and $\mathrm{Rb}-\mathrm{Sr}$ mineral ages. Geological Society of America Bulletin 102, 653-63.

Dallmeyer, R. D., Peucat, J. J., Hirajima, T. \& OHta, Y. 1990. Tectonothermal chronology within a blueschist-eclogite complex, westcentral Spitsbergen, Svalbard: evidence from ${ }^{40} \mathrm{Ar} /{ }^{39} \mathrm{Ar}$ and $\mathrm{Rb}-\mathrm{Sr}$ mineral ages. Lithos 24, 291-304.

Dalrymple, G. B., Alexander, E. C. JR., Lanphere, M. A. \& KRAKER, G. P. 1981. Irradiation of samples for ${ }^{40} \mathrm{Ar}{ }^{39} \mathrm{Ar}$ dating using the Geological Survey TRIGA reactor. U.S. Geological Survey Professional Paper no. 1176.

Gavrilenko, B. V., Balasov, Ju. A., Tebenkov, A. M. \& LARIONOV, A. N. 1993. U-Pb early Proterozoic age of "relict" zircon from high potassium quartzose porphyries of Wedel Jarlsberg Land, SW Spitsbergen. Geochimija 1, $154-8$.

Gayer, R. A., Gee, D. G., Harland, W. B., Miller, J. A., Spall, H. R., Wallis, R. H. \& Winsnes, T. S. 1966. Radiometric age determinations on rocks from Spitsbergen. Norsk Polarinstitutt Skrifter 137, 1-39.

Hamilton, E. I. \& SANFORD, K. S. 1964. Rubidium-strontium age from North-East Land (Spitsbergen). Nature 201, 1208-9.

HoRSFIELD, W. T. 1972. Glaucophane schists of Caledonian age from Spitsbergen. Geological Magazine 109, 29-36.

LAuRITZEN, O. \& OHTA, Y. 1984. Geological Map, Svalbard, Sheet 4G, Nordaustlandet, scale 1:500000. Norsk Polarinstitutt Skrifter 154D.

Lux, D. R. $1986 .{ }^{40} \mathrm{Ar} /{ }^{39} \mathrm{Ar}$ ages for minerals from the amphibolite dynamothermal aureole, Mont Albert, Gaspe, Quebec. Canadian Journal of Earth Sciences 23, 21-6.

McDougall, I. \& HarRISON, T. M. 1988. Geochronology and thermochronology by the Ar/Ar method. New York: Oxford University Press.

Ohta, Y., Dallmeyer, R. D. \& Peucat, J. J. 1989. Caledonian terranes in Svalbard. Geological Society of America Special Paper 230, 1-15.

OнтA, Y. 1994. Caledonian and Precambrian history in Svalbard: A review and an implication of escape tectonics. Tectonophysics 231, 183-94.

Peucat, J. J., Ohta, Y., Gee, D. G. \& Bernard-Griffiths, J. 1989. U-Pb, Sr and Nd evidence for Grenvillian and latest Proterozoic tectonothermal activity in the Spitsbergen Caledonides, Arctic Ocean. Lithos 22, 275-85. 